\title{
The crucial role of mulch to enhance the stability and resilience of cropping systems in southern Africa
}

\author{
Blessing Mhlanga ${ }^{1}$ (ID $\cdot$ Laura Ercoli $^{1} \cdot$ Elisa Pellegrino ${ }^{1} \cdot$ Andrea Onofri $^{2} \cdot$ Christian $^{\text {Thierfelder }}{ }^{3}$
}

Accepted: 16 March 2021 / Published online: 8 April 2021

(C) The Author(s) 2021

\begin{abstract}
Conservation agriculture has been promoted to sustainably intensify food production in smallholder farming systems in southern Africa. However, farmers have rarely fully implemented all its components, resulting in different combinations of no-tillage, crop rotation, and permanent soil cover being practiced, thus resulting in variable yield responses depending on climatic and soil conditions. Therefore, it is crucial to assess the effect of conservation agriculture components on yield stability. We hypothesized that the use of all three conservation agriculture components would perform the best, resulting in more stable production in all environments. We evaluated at, eight trial locations across southern Africa, how partial and full implementation of these components affected crop yield and yield stability compared with conventional tillage alone or combined with mulching and/ or crop rotation. Grain yield and shoot biomass of maize and cowpea were recorded along with precipitation for 2 to 5 years. Across different environments, the addition of crop rotation and mulch to no-tillage increased maize grain by $6 \%$, and the same practices added to conventional tillage led to $13 \%$ yield increase. Conversely, adding only mulch or crop rotation to no-tillage or conventional tillage led to lower or equal maize yield. Stability analyses based on Shukla's index showed for the first time that the most stable systems are those in which mulch is added without crop rotation. Moreover, the highest yielding systems were the least stable. Finally, additive main effects and multiplicative interaction analysis allowed clarifying that mulch added to no-tillage gives stable yields on sandy soil with high rainfall. Similarly, mulch added to conventional tillage gives stable yield on sandy soil, but under low rainfall. This is the first study that highlighted the crucial role of mulch to enhance the stability and resilience of cropping systems in southern Africa, supporting their adaptability to climate change.
\end{abstract}

Keywords Sustainable intensification $\cdot$ No-tillage $\cdot$ Southern Africa $\cdot$ Conservation agriculture $\cdot$ Yield stability

\section{Introduction}

Conservation agriculture (CA) is a multi-component cropping system composed of (i) no-tillage, (ii) maintenance of permanent soil cover with organic material, and (iii) crop diversification. It has shown potential to improve productivity, protect the environment, and reduce production costs in southern

Blessing Mhlanga

b.mhlanga@santannapisa.it

1 Scuola Superiore Sant'Anna, Institute of Life Sciences - BioLabs, Pisa, Italy

2 Dipartimento di Scienze Agrarie, Alimentari e Ambientali, Università degli Studi di Perugia, Perugia, Italy

3 International Maize \& Wheat Improvement Centre (CIMMYT), Southern Africa Regional Office (SARO), Harare, Zimbabwe
Africa (FAO 2012). Moreover, other studies showed positive effects of CA on agronomic and economic as well as soil health aspects (Ercoli et al. 2017). Conservation agriculture improves soil properties such as water infiltration, soil microbial biomass, and amount of water stable aggregates (Esmeraldo 2017; Thierfelder and Wall 2009). A gradual increase in soil carbon (SOC) was also observed, leading to $+24 \%$ in the fifth year of CA implementation (Ligowe et al. 2017). Compared with conventional tillage (CT), CA has been shown to increase SOC by between 0.28 and $0.96 \mathrm{Mg} \mathrm{C}^{-1}$ per year in $0-30 \mathrm{~cm}$ soil depth in sub-Saharan Africa (Powlson et al. 2016). However, the response depends to a large extent on context and site-specific management (Cheesman et al. 2016). The covering of soil with crop residues increases water infiltration through stimulation of macrofaunal activity, reduction in soil surface disturbance, and increase of water conducting pores in sandy and clay loamy soils (Thierfelder et al. 2014). Under low rainfall conditions, 
no-tillage and mulching with aboveground crop residues are likely to enhance crop yields, support macrofaunal populations, reduce weed pressure, and improve water retention (Thierfelder and Wall 2010; Mhlanga et al. 2015; Craven and Nel 2017; Steward et al. 2018, 2019).

Nevertheless, there is also evidence of negative effects of CA components under varying conditions. For example, notillage resulted in lower maize (Zea mays L.) yields as compared with tillage in two locations in Zambia for two consecutive years (Mafongoya and Jiri 2015). A meta-analysis by Pittelkow et al. (2015) comparing no-tillage with conventional tillage revealed on average a reduction of yield by $5.7 \%$, but the effect was highly variable, depending on soil type, rainfall, duration of implementation, and previous land use. Therefore, improved implementation including complementary practices (i.e., mulching and/or rotation) is necessary to optimize no-till performance (Thierfelder et al. 2018).

In this context, the adoption of CA by smallholder farmers in southern Africa is low (Ward et al. 2018) and accounts only for $0-10 \%$ of arable land use in various countries (Kassam et al. 2019). A study by Ngwira et al. (2014) in six districts of Malawi showed that by 2014 only $18 \%$ of the farmers had adopted some form of $\mathrm{CA}$ and this represented $2 \%$ of the cultivated land. Depending on the socio-economic and biophysical conditions, farmers may find it easier to adopt certain components or combinations of components (Ward et al. 2018). There has been some debate in the literature that farmers may find it more feasible to adopt only one of the CA components at a time in a so-called "ladder approach", although other schools of thought argue for a full implementation of CA, but starting on a small piece of land and extending the practice on the remaining land later (Thierfelder et al. 2018). The latter recommendation is based on the notion that there are synergies among the CA components, whose benefits can only be attained upon full implementation of all CA practices (Thierfelder et al. 2013). However, logistical and organizational hurdles may be prohibitive for farmers (Giller et al. 2015), which makes it important to determine which combinations of the three CA components are most beneficial for crop yield.

Characteristics of farm organization play an important role in decision making on which CA components are adopted (Hermans et al. 2020). Farmers with only small cultivable land, for example, are less likely to adopt crop rotation, as compared with farmers who are able to cultivate large areas. Lack of access to legume seed and output markets for legume crops is a setback for other smallholders, which hampers systematic legume rotation (Ngwira et al. 2014). The competition for the use of crop residues between retaining them as ground cover and feeding them to cattle as fodder can also result in the low adoption of permanent soil cover in communities characterized by crop-livestock farming (Valbuena et al. 2012). Yet, successful adoption of CA components should be associated with good agronomic practices, such as adequate fertilizer application and timely weeding, which farmers may not afford or tend to overlook, resulting in reduced yields despite having adopted the CA components (Nyamangara et al. 2014; Thierfelder et al. 2018).

In southern Africa, there is some evidence of idiosyncratic differences in yield among farmers that adopted all the three components of CA (full adopters) and farmers that only adopted either one or two components of CA (partial adopters), probably due to environmental context dependencies (Brouder and Gomez-Macpherson 2014). Although considerable effort has been made to understand crop yield response to different CA component interactions, to our knowledge, no work has assessed these responses together with dynamic yield stability under different environmental conditions. This is an important aspect since yield and yield stability are fundamental in defining productivity and resilience of cropping systems under climate change scenarios. Some studies have shown that yield under CA improves over time (Corbeels et al. 2020), but an assessment of the benefits on the basis of yield stability would also be meaningful for early adopters. Thus, the aim of this study was to evaluate the interactive effects of the components of CA on grain yield and yield stability of maize as the main crop and cowpea as the rotational crop under different soil and climatic conditions across southern Africa. We hypothesized that the use of all three CA components would perform the best and result in more stable production in all environments. This was tested using data of eight CA trials in four countries (Fig. S1), each with all eight cross-factorial combinations of the three CA components. In Fig. 1, examples of cropping systems based on different combinations of CA components are shown.

\section{Materials and methods}

\subsection{Study locations}

The CA trials were run at eight locations in Mozambique, Namibia, Zambia, and Zimbabwe. The study locations were the Ntengo Umodzi Research Station (NURS), Sussundenga Research Station (SRS), Lisello Training Centre (LRS), Misamfu Research Station (MiRS), Monze Farmer Training Centre (MFTC), Msekera Research Station (MRS), Domboshava Training Centre (DTC), and University of Zimbabwe farm (UZ) (Fig. S1). The trials were implemented over variable years at the different locations: NURS, 2014 2016; SRS, 2014-2015; LRS, 2017-2018; MFTC, 2014 2018; MiRS, 2016-2018; MRS, 2015-2018; DTC, 2014 2018; and UZ, 2014-2018. More information on the geographical coordinates, altitude, mean annual temperature, and years of trial execution are listed in Table 1 . 
Fig. 1 Examples of cropping systems based on different combinations of conservation agriculture (CA) components, as in the field trials set up across eight experimental locations in southern Africa: (a) conventionally tilled maize (Zea mays L.) plus mulch; (b) conventionally tilled maize rotated with cowpea (Vigna unguiculata L.) plus mulch; (c) no-tillage maize with mulch; and (d) a complete $\mathrm{CA}$ with no-tillage, mulch, and rotation of maize and cowpea. Photos: CIMMYT, C. Thierfelder
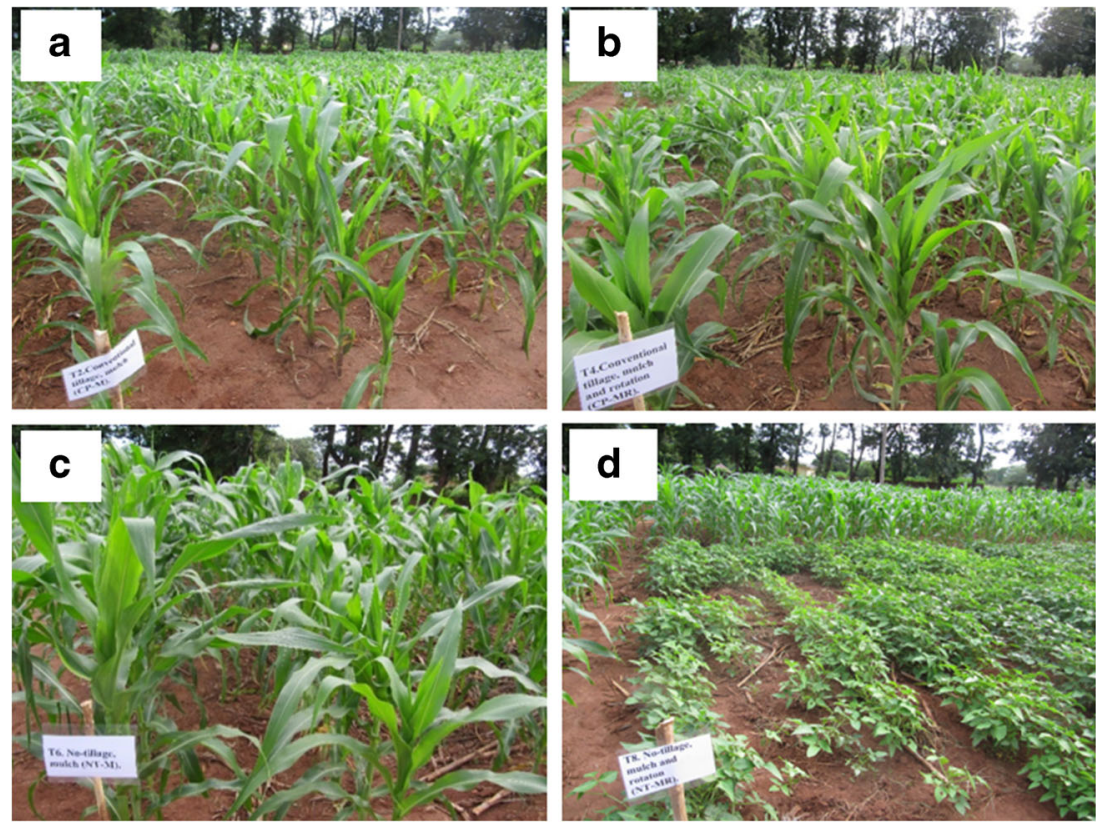

Classification of the soils, soil texture, and organic carbon (C) content are also listed in Table 1.

\subsection{Annual rainfall distribution and interannual variability at the study locations}

Daily rainfall was recorded at each location and cumulative values for the whole cropping stage were calculated per location and year. Rainfall from sowing to the end of the vegetative stage (stage V18; Hanway 1963), hereafter referred to as P.veg, and rainfall from the beginning of the reproductive stage of silk emergence (stage R1) to harvest, hereafter called P.rep, were additionally calculated. Precipitation followed a unimodal pattern, usually starting in the first week of November (Fig. 2) after which the crops were sown. The cropping seasons at all locations started in November and ended in April. Total rainfall during the growing season of maize averaged across all locations was $825 \mathrm{~mm}$, but greatly differed among locations, averaging from $483 \mathrm{~mm}$ at LRS to $1103 \mathrm{~mm}$ at MiRS (Fig. 2). Rainfall was also highly variable among the years at most locations: the within-location coefficient of variation (CV) was higher than $20 \%$ for five (DTC, UZ, MFTC, MRS, and NURS) of the eight locations. The highest variability was recorded at NURS $(\mathrm{CV}=35.1 \%)$, while the lowest was at $\mathrm{LRS}(\mathrm{CV}=1.0 \%)$.

The interannual variation in rainfall during the vegetative growth stage (P.veg) was high at NURS $(\mathrm{CV}>50 \%)$ and during the reproductive stage (P.rep) was high at UZ (CV > $50 \%$ ). For all locations, the CV for P.veg and P.rep were above $10 \%$. Drought periods lasted up to 21 days for sites such as LRS (Fig. 2).

\subsection{Design of the trials}

At each location, the experiments were set up as randomized complete block designs with four blocks (plot size: $12 \mathrm{~m} \times 6$ $\mathrm{m}$ ) and eight treatments (cropping systems) based on either conventional tillage (CT) or no-tillage (NT) and with both phases of a rotation in each year. Illustration of basis of formulation of treatments is given in Fig. S2:
i. Conventional tillage (CT)
ii. Conventional tillage plus mulch $(\mathrm{CT}+\mathrm{M})$
iii. Conventional tillage plus rotation $(\mathrm{CT}+\mathrm{R})$
iv. Conventional tillage plus mulch and rotation $(\mathrm{CT}+\mathrm{M}+\mathrm{R})$
v. No-tillage (NT)
vi. No-tillage plus mulch $(\mathrm{NT}+\mathrm{M})$
vii. No-tillage plus rotation $(\mathrm{NT}+\mathrm{R})$
viii. No-tillage plus mulch and rotation $(\mathrm{NT}+\mathrm{M}+\mathrm{R})$, referred to as $\mathrm{CA}$ or complete CA.

Conventional tillage (CT) involved the use of hand hoes to simulate ploughing and to create small planting basins into the tilled soil in which the seeds and basal NPK fertilizer were placed at the beginning of each growing season. The NT treatment involved no tillage and just creation of planting basins (usually at the size of $15 \mathrm{~cm} \times 15 \mathrm{~cm} \times 15 \mathrm{~cm}$ ) for seed and fertilizer placement or ripping by animal traction and manual seed and fertilizer placement into the rip lines. For treatments that involved mulching (+M), maize (Zea mays L.), or cowpea (Vigna unguiculata $\mathrm{L}$.), residues were retained on the soil surface under NT or placed back after tillage under CT, whereas for treatments without mulching residues were removed at crop harvest. Approximately $2.5-3 \mathrm{t} \mathrm{ha}^{-1}$ of the residues of the previous crop 


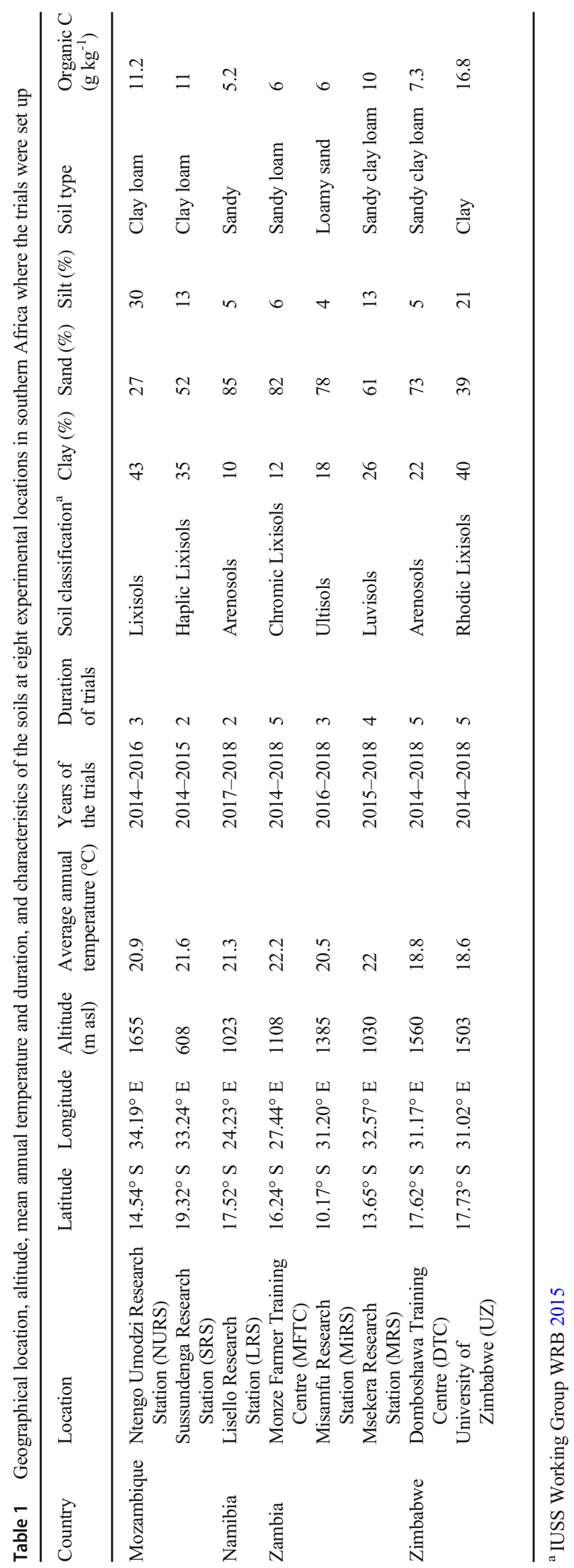


Fig. 2 Cumulative rainfall at the eight locations over two to five growing seasons 2014 (blue line), 2015 (red line), 2016 (green line), 2017 (black line), and 2018 (purple line). The coefficient of variation $(\mathrm{CV})$ of total rainfall (P.tot), rainfall from sowing to the end of vegetative stage (P.veg), and rainfall from the start of reproductive stage to physiological maturity (P.rep) among seasons is given as an indicator of the variability among seasons at each location.

Abbreviations of the trial locations: NURS, Ntengo Umodzi; SRS, Sussundenga Research Station; LRS, Lisello Research Station; MiRS, Misamfu Research Station; MFTC, Monze Farmer Training Centre; MRS, Msekera Research Station; DTC, Domboshava Training Centre; UZ, University of Zimbabwe farm. The values in front of each line represent the total seasonal rainfall received in millimeters
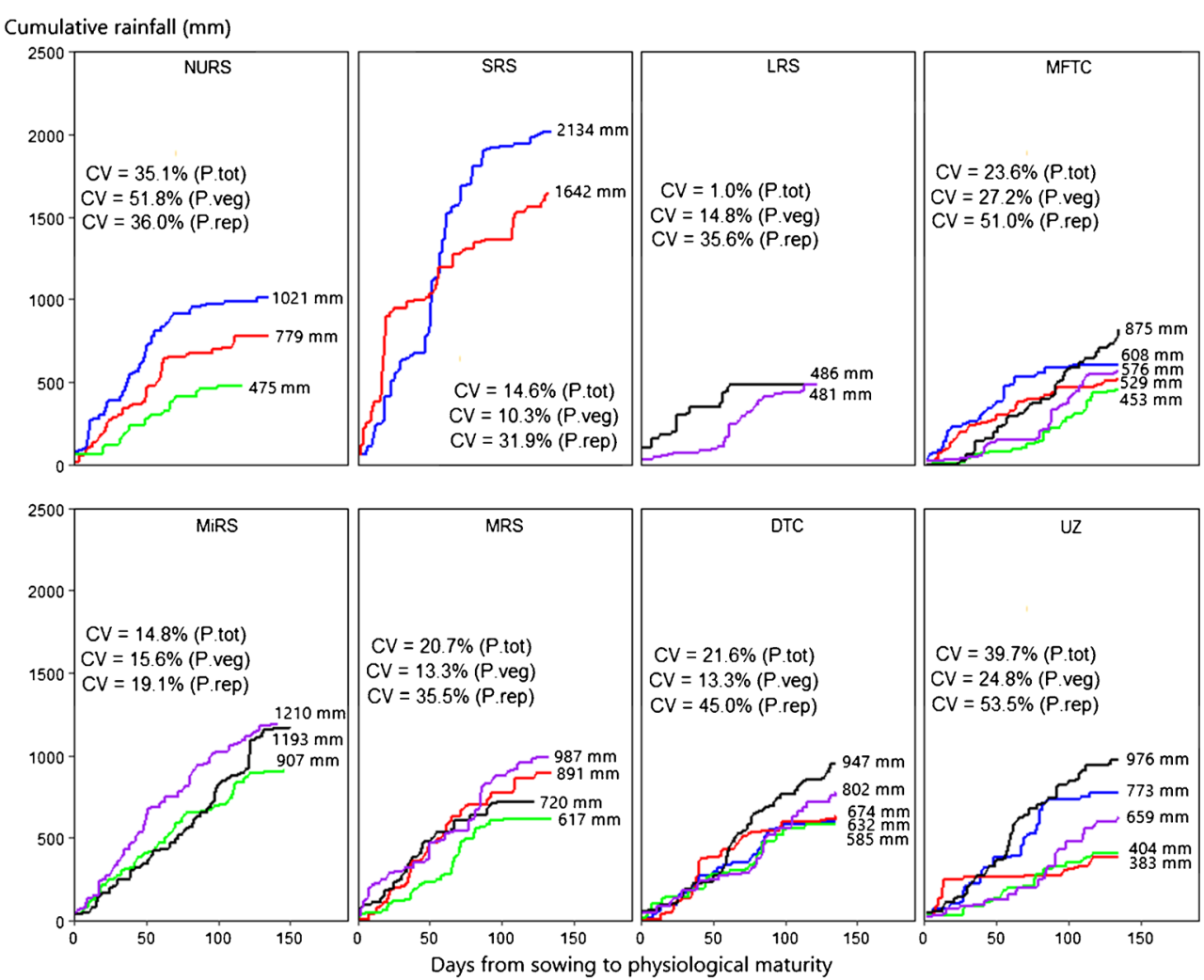

was evenly spread on the soil surface at the beginning of each season. For treatments that involved crop rotation $(+\mathrm{R})$, maize was rotated with cowpea in all locations. Both crops were sown in each year by splitting the rotational plots into two half-sized subplots $(6 \mathrm{~m} \times 6 \mathrm{~m})$. Since both crops were present in each year, there were 12 plots, representing the different experimental treatments (i.e., cropping systems) per block: eight systems with maize and four systems with cowpea.

Both maize and cowpea were grown under rain-fed conditions at all locations. Maize was sown at a density of 44,444 plants ha ${ }^{-1}$ with $90 \mathrm{~cm}$ spacing between the rows and $25 \mathrm{~cm}$ within rows after receiving the first effective rains of more than $30 \mathrm{~mm}$ within 2 days after the beginning of November. Cowpea was sown at a density of 111,111 plants ha ${ }^{-1}$ with $45 \mathrm{~cm}$ spacing between the rows and $20 \mathrm{~cm}$ within rows, planted on the same date as maize. Only in the trial at the location LRS maize was sown at a density of 37,746 plants ha ${ }^{-1}(90 \mathrm{~cm}$ between rows and $35 \mathrm{~cm}$ within rows), due to the very low local rainfall and the need to adjust plant populations. The maize varieties were medium (110-135 days) and late (140-155 days) maturing (Table S1). The cowpea varieties were medium maturing and reached maturity at about 90 days after emergence.

\subsection{Fertilizer application, weed control}

Mineral NPK fertilizer was applied at sowing in all cropping systems and to both crops as a basal dressing as locally recommended (Table S2). Additional $\mathrm{N}$ fertilizer was applied as top dressing to maize only in all treatments in the form of ammonium nitrate or urea and at stages V4 and V7 (about 4 and 7 weeks after sowing) (Zhao et al. 2011). Doses were chosen based on local fertilizer application recommendations. Weeds were controlled across all plots by early pre-emergence herbicide treatment (glyphosate at $1.025 \mathrm{~L}$ a.i. $\mathrm{ha}^{-1}$ ). Late emerging weeds were removed manually, using a hand hoe.

\subsection{Crop harvesting}

Plants of maize and cowpea from an area of $18 \mathrm{~m}^{2}(5 \mathrm{~m} \times 3.6$ $\mathrm{m})$ were manually harvested at physiological maturity (stage R6) and oven-dried grain yield and shoot biomass were determined. Values were adjusted to $12.5 \%$ water for maize and $9.0 \%$ water for cowpea and yields were expressed in $\mathrm{tha}^{-1}$.

\subsection{Data analysis}

Data were analyzed by a mixed model statistical analysis using cropping system (abbreviated as system) as the only fixed factor. The locations, blocks nested within locations, plots nested within blocks nested within locations, and years nested within locations were included as random factors, to account for grouping factors and repeated measures across years in the same plots (Onofri et al. 2016). We defined a new factor called environments based on the combinations 
of locations and years (location $\times$ year cross classification). This meant that there were 29 combinations of "location $\times$ year" for maize data and 25 combinations for cowpea data (due to missing cowpea data for some years). The interaction of the environments and systems (environment $\times$ system) was also included in the statistical model as a random effect to determine the context dependency of grain yield and shoot biomass. The formulas of the models used in the analyses are given below (Eq. 1):

$$
\begin{aligned}
\gamma_{i j k} & \sim \mu+\text { System }_{i}+\text { Location }_{j}+\left(\text { Location }_{j} \times \text { Year }_{k}\right) \\
& +\left(\text { System }_{i} \times \text { Location }_{j} \times \text { Year }_{k}\right) \\
& +\left(\text { Location }_{j} \mid \text { Block }\right)+\left(\text { Location }_{j} \mid \text { Block } \mid \text { Plot }\right) \\
& +\xi_{i j k}
\end{aligned}
$$

where $\gamma_{\mathrm{ijk}}$ is the mean grain yield in the $i$ th system, $j$ th location, and $k$ th year; $\mu$ is the overall mean; System $_{i}$ is the fixed effect of the $i$ th system; Location $_{j}$ is the random effect of the $j$ th location; Location $_{j} \times$ Year $_{k}$ is the random interactive effect of the $j$ th location and $k$ th year; System ${ }_{i} \times$ Location $_{j} \times$ Year $_{k}$ is the random interactive effect of the $i$ th cropping system, $j$ th location and $k$ th year; Location ${ }_{j}$ Block is the random effect of the block within the $j$ th location; Location ${ }_{j} \mid$ Block|Plot is the random effect of the plot within the block within the $j$ th location; and $\xi_{\mathrm{ijk}}$ is the random residual effect.

The variance components for the random effects were estimated by using restricted maximum likelihood (REML) as implemented by the Asreml-R package (Butler et al. 2009) and also by lme4 package (Bates et al. 2015) in the R statistical environment (R Core Team 2019). Graphical analysis of the residuals was used to assess the homoscedasticity and normality of the data. The significance of fixed experimental effects was tested by Wald chi-square tests. Means were compared using a multiple comparison procedure with single-step multiplicity adjustment (Bretz et al. 2016), as implemented in the emmeans package of R (Lenth 2019).

To make further comparisons between selected cropping systems (i.e., maize: $\mathrm{CT}+\mathrm{M}+\mathrm{R}$ vs $\mathrm{CT}$, $\mathrm{NT}+\mathrm{R}+\mathrm{M}$ vs NT, and $\mathrm{NT}+\mathrm{R}+\mathrm{M}$ vs $\mathrm{CT}+\mathrm{M}+\mathrm{R}$; cowpea: $\mathrm{NT}+\mathrm{R}+\mathrm{M}$ vs $\mathrm{CT}+\mathrm{M}+\mathrm{R}$ ), best linear unbiased predictors (BLUPs) for the "system $\times$ environment" combinations were extracted from the linear mixed model fits described in the previous section and plotted. These BLUPs of random factors correspond to the fitted values of fixed factors and were used here to estimate crop yields under all system $\times$ environment combinations. The use of BLUPs is more desirable as compared with the means of the observed data since they are centered toward the overall mean (Piepho 1998b).

Grain yield and shoot biomass stability of each cropping system across environments were assessed using the dynamic concept of stability based on Shukla's stability variance $\left(\widetilde{\sigma}_{i}^{2}\right)$
(Shukla 1972) which assesses yield variability across a set of selected environments. In the analyses, this index was estimated by REML, allowing the variance components for the interaction of "cropping systems $\times$ environments" to vary across cropping systems (Piepho 1998), using the idho function in Asreml-R. The cropping systems with lower values of stability variance are regarded as more stable (Urruty et al. 2016).

To better explain the pattern of stability of the cropping systems, the two-way table of BLUPs calculated above was submitted to additive main effects and multiplicative interaction (AMMI) analyses (Zobel et al. 1988) and the results were displayed in AMMI2 biplots (Gauch et al. 2008). Again, the use of BLUPs was preferred over the observed means due to their centeredness toward the overall mean and hence better representing the relative (i.e., dynamic) yield stability. Briefly, in the AMMI analyses, the BLUPs were double centered to remove the main effects and the principal components of each cropping system were calculated using singular value decomposition in the vegan package of $\mathrm{R}$ (Oksanen et al. 2019). Methods such as AMMI as well as the interpretation of the biplots have been previously used to predict stability of cropping systems under rain-fed conditions in the context of long-term agronomic experiments (e.g., Bonciarelli et al. 2016). Intrinsically, Shukla's stability variance and AMMI analysis provide complementary and non-overlapping information. The Shukla variance gives an index of variability, whereas AMMI analysis gives information on the basic pattern of stability, allowing for the ordination of cropping systems and environments based on their reciprocal relationship on the AMMI2 biplot. To better understand the ordination of the cropping systems, several environmental factors that included the amounts of applied nitrogen $\left(\mathrm{kg} \mathrm{ha}^{-1}\right)$, phosphorus $\left(\mathrm{kg} \mathrm{ha}^{-1}\right)$, potassium $\left(\mathrm{kg} \mathrm{ha}^{-1}\right)$; soil clay, sand, and organic carbon content $\left(\mathrm{g} \mathrm{kg}^{-1}\right)$, total rainfall over the growing season $(\mathrm{mm})$ (P.tot), rainfall received during the vegetative period (mm) (P.veg), and rainfall received during the reproductive period (P.rep) ( $\mathrm{mm}$ ) were projected on the AMMI2 biplots using the envfit() function (Borcard et al. 2018) in the vegan package of R.

\section{Results and discussion}

\subsection{Grain yield and shoot biomass}

Maize grain yield differed significantly among the cropping systems (Wald $\chi^{2}=21.0$, d.f. $=7, p<0.05$ ), as did shoot biomass (Wald $\chi^{2}=25.1$, d.f. $=7, p<0.001$ ) (Table 2).

Maize grain yield was highest with $\mathrm{CT}+\mathrm{M}+\mathrm{R}$, lowest with $\mathrm{CT}$, NT, and NT+M, and intermediate with the other treatments (Fig. 3a). Compared with $\mathrm{CT}, \mathrm{CT}+\mathrm{M}$, and $\mathrm{CT}+\mathrm{R}$, the $\mathrm{CT}+\mathrm{M}+\mathrm{R}$ system increased grain yield by $13 \%, 14 \%$, and $7 \%$, respectively. Similarly, the NT+R+M system increased grain 
Table 2 Results of mixed model analysis on the effect of eight cropping systems (i.e., conventional tillage-CT, CT plus mulch-M, CT plus rotation- $\mathrm{R}, \mathrm{CT}+\mathrm{M}+\mathrm{R}$, no-tillage- $\mathrm{NT}, \mathrm{NT}+\mathrm{M}, \mathrm{NT}+\mathrm{R}, \mathrm{NT}+\mathrm{M}+\mathrm{R}$ ) on grain yield and shoot biomass of maize (Zea mays L.) and of four cropping systems (i.e., $\mathrm{CT}+\mathrm{R}, \mathrm{CT}+\mathrm{M}+\mathrm{R}, \mathrm{NT}+\mathrm{R}, \mathrm{NT}+\mathrm{M}+\mathrm{R}$ ) on those of cowpea (Vigna unguiculata L.) across eight experimental locations in southern Africa, with four field replicates for each cropping system, and trial duration from 2 to 5 years

\begin{tabular}{|c|c|c|c|c|c|c|}
\hline \multirow[t]{2}{*}{ Crop } & \multirow[t]{2}{*}{ Source } & \multirow[t]{2}{*}{$\mathrm{df}$} & \multicolumn{2}{|l|}{ Grain yield } & \multicolumn{2}{|l|}{ Shoot biomass } \\
\hline & & & Sum of squares & Wald statistic & Sum of squares & Wald statistic \\
\hline \multirow[t]{3}{*}{ Maize } & Intercept & 1 & 88163034 & $94.516^{* * *}$ & 68602727 & $78.485 * * *$ \\
\hline & Cropping system & 7 & 19626845 & $21.041 * *$ & 21901749 & $25.057 * * *$ \\
\hline & Residuals & & 932782 & & 874087 & \\
\hline \multirow[t]{3}{*}{ Cowpea } & Intercept & 1 & 7963198 & $86.281 * * *$ & 10571261 & $29.825 * * *$ \\
\hline & Cropping system & 3 & 242506 & $2.628^{\mathrm{ns}}$ & 336130 & $0.8138^{\mathrm{ns}}$ \\
\hline & Residuals & & 92294 & & 354446 & \\
\hline
\end{tabular}

$n s$, not significant; $* p<0.05 ; * * p<0.01 ; * * * p<0.001$

yield by $6 \%$ and $8 \%$ compared with $\mathrm{NT}$ and $\mathrm{NT}+\mathrm{M}$, respectively, while no change was observed in comparison with $\mathrm{NT}+\mathrm{R}$. Maize shoot biomass was highest with $\mathrm{CT}+\mathrm{M}+\mathrm{R}$ and lowest with NT and NT+M, with a similar pattern to grain yield for the other treatments (Fig. 3c).

In a meta-analysis across the world, Pittelkow et al. (2015) reported that maize yield was reduced under NT compared with $\mathrm{CT}$, but the negative impacts of NT decreased when rotation and mulch were implemented. However, when the influence of climate (i.e., rainfall) is taken into consideration, in dry environments positive effects (+7\%) of full CA and negative or no effects of NT alone or in combination with rotation or mulch were reported (Pittelkow et al. 2015). By contrast, in humid climates, yields of rainfed field crops decreased with NT irrespective of the implementation with rotation or mulching. Thus, our multi-location and year comparison study, although not confirming the yield gap between NT and CT, supports the crucial role of implementing rotation and mulch under NT as well as under $\mathrm{CT}$ in order to obtain the highest maize yield. The insights from our study thus further emphasize that change to NT should
Fig. 3 Average grain yield and shoot biomass of maize (Zea mays L.) (a and c, respectively) and of cowpea (Vigna unguiculata L.) (b and d, respectively), for each cropping system, calculated across eight experimental locations in southern Africa, with four field replicates for each cropping system, and trial duration from 2 to 5 years. Abbreviations of cropping systems: CT, conventional tillage; $\mathrm{CT}+\mathrm{M}, \mathrm{CT}$ plus mulch; $\mathrm{CT}+\mathrm{R}, \mathrm{CT}$ plus crop rotation; $\mathrm{CT}+\mathrm{M}+\mathrm{R}, \mathrm{CT}$ plus mulch and rotation; NT, notillage; NT+M, NT plus mulch; $\mathrm{NT}+\mathrm{R}$, NT plus rotation; $\mathrm{NT}+\mathrm{M}+$ $\mathrm{R}, \mathrm{NT}$ plus mulch and rotation. Raincloud plots with different superscript letters are significantly different at $0.05 \%$ probability level and NS signify no significant differences. The jittered points represent individual observations in all locations and years

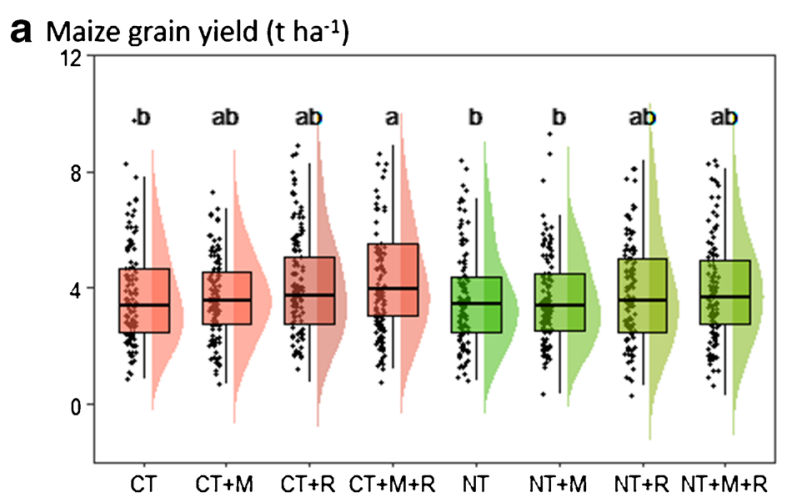

b Cowpea grain yield $\left(t \mathrm{ha}^{-1}\right)$
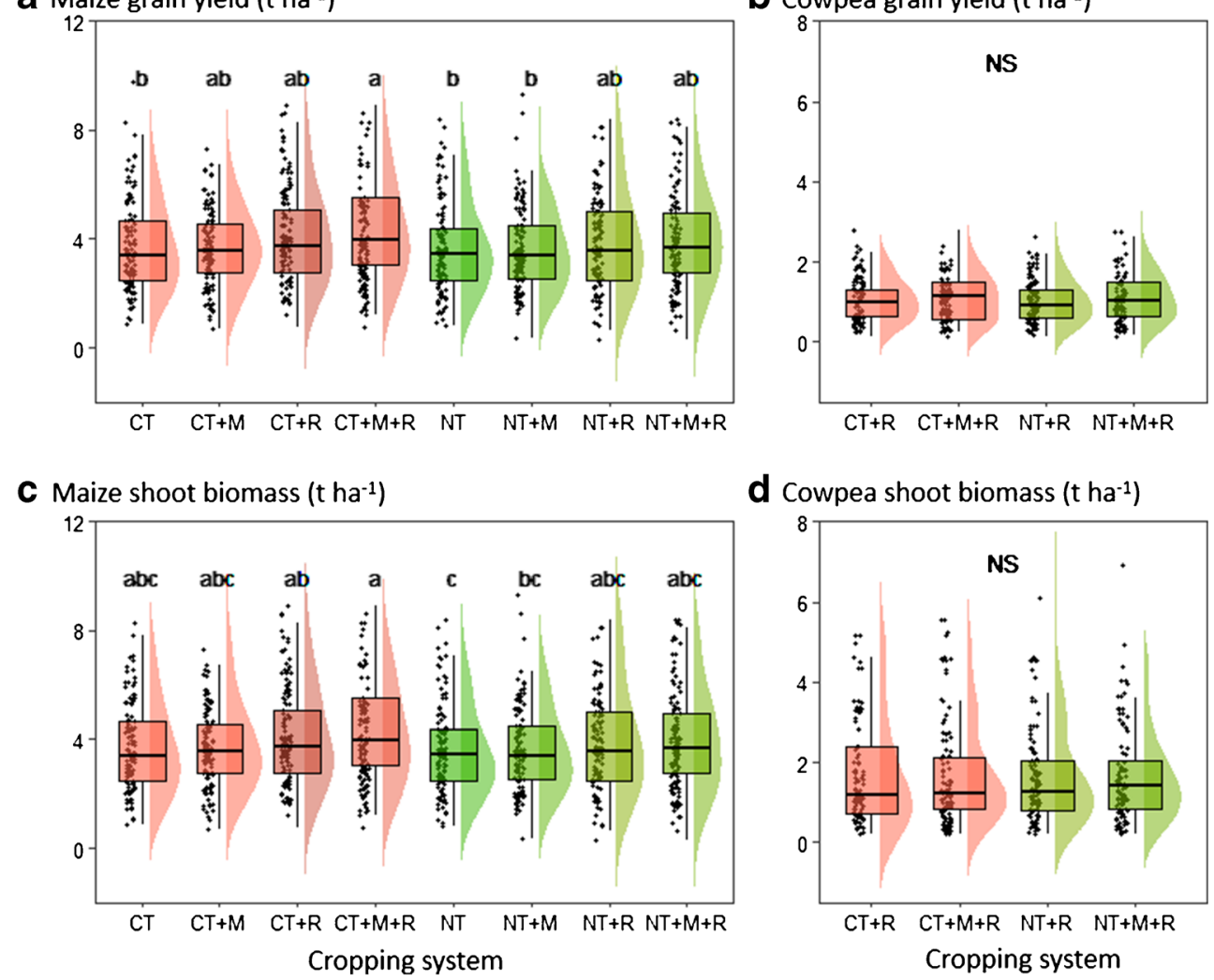

d Cowpea shoot biomass $\left(t \mathrm{th}^{-1}\right)$

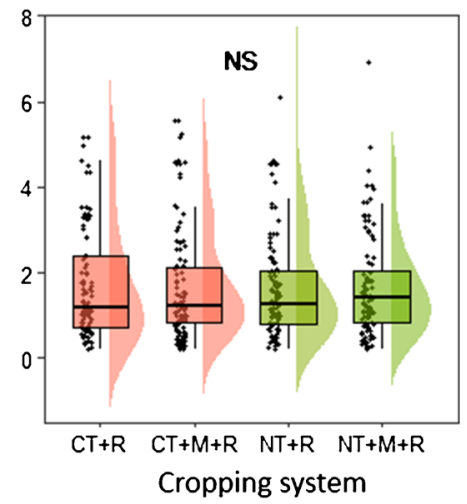


not be the first step towards adoption of CA practices to avoid reductions of yield (Ngwira et al. 2014a, b; Thierfelder et al. 2013; Kodzwa et al. 2020).

Grain yield and biomass of cowpea did not differ among the cropping systems and were on average $1.1 \mathrm{t} \mathrm{ha}^{-1}$ and $1.7 \mathrm{t}$ $\mathrm{ha}^{-1}$, respectively (Table 2 and Fig. 3b, d). Similarly, legume crop yields were shown to be unaffected by tillage system (NT vs CT) and by the implementation of CA practices, such as rotation or mulch (Pittelkow et al. 2015). Our results on cowpea support the hypothesis of Pittelkow et al. (2015) that legume crops are less susceptible than cereals to potential yield limiting factors associated with NT (e.g., soil compaction and nutrient availability).

To understand the differences in performance between $\mathrm{CT}+$ $\mathrm{M}+\mathrm{R}$ and $\mathrm{CT}$ (which we considered the current conventional farmers' practice) and between $\mathrm{NT}+\mathrm{M}+\mathrm{R}$ (which we considered full CA) and NT in individual sites, we used the differences of BLUPs of these systems. These analyses on maize grain yield and shoot biomass revealed that $\mathrm{CT}+\mathrm{M}+\mathrm{R}$ outperformed $\mathrm{CT}$ in $86 \%$ and $90 \%$ of all environments, respectively (Fig. 4a).
Similarly, NT+M+R outperformed NT grain yield and shoot biomass in $76 \%$ and $90 \%$ of all environments, respectively (Fig. 4b). The interaction of locations and years (environments) explained on average $36 \%$ of the variance in grain yield and shoot biomass of maize, while the study locations explained on average $28 \%$ (Fig. S5). Our results highlighted for the first time that the positive response in terms of maize yield due to the implementation of rotation and mulch is generalized across environments in southern Africa and this is in contrast with previous reports in the same climatic region highlighting strong effects of climate stress and soil texture only (Steward et al. 2018). Indeed, in this meta-analysis, full CA performed better than CT under scenarios of drought and/or heat stress, but the response was modulated by soil texture. In very wet seasons, CA outyields CT in sandy soils having poor water holding capacity as opposed to soils with higher clay content, where it consistently underperforms (Steward et al. 2018). Unexpectedly, in our study, the $\mathrm{CT}+\mathrm{M}+\mathrm{R}$ system which is rarely applied in southern Africa outyielded full implementation of CA in most environments (83\%), with the exception of environments with sandy soils
Fig. 4 Difference between best linear unbiased predictors (BLUPs) of (a) conventional tillage plus mulch and rotation $(\mathrm{CT}+\mathrm{M}+\mathrm{R})$ and $\mathrm{CT}$, and of $(\mathbf{b})$ no-tillage plus mulch and rotation $(\mathrm{NT}+\mathrm{M}+\mathrm{R})$ and $\mathrm{NT}$ for maize (Zea mays L.) grain yield (blue points and error bars) and shoot biomass (red points and error bars) at eight experimental locations in southern Africa and in all studied years

(Environments). The error bars represent standard errors of four field replicates for each cropping system. Abbreviations of the trial locations: NURS, Ntengo Umodzi; SRS, Sussundenga Research Station; LRS, Lisello Research Station; MiRS, Misamfu Research Station; MFTC, Monze Farmer Training Centre; MRS, Msekera Research Station; DTC, Domboshava Training Centre; UZ, University of Zimbabwe farm a Difference of BLUPs of ' $C T+M+R^{\prime}$ and ' $C T$ ' (t ha-1)

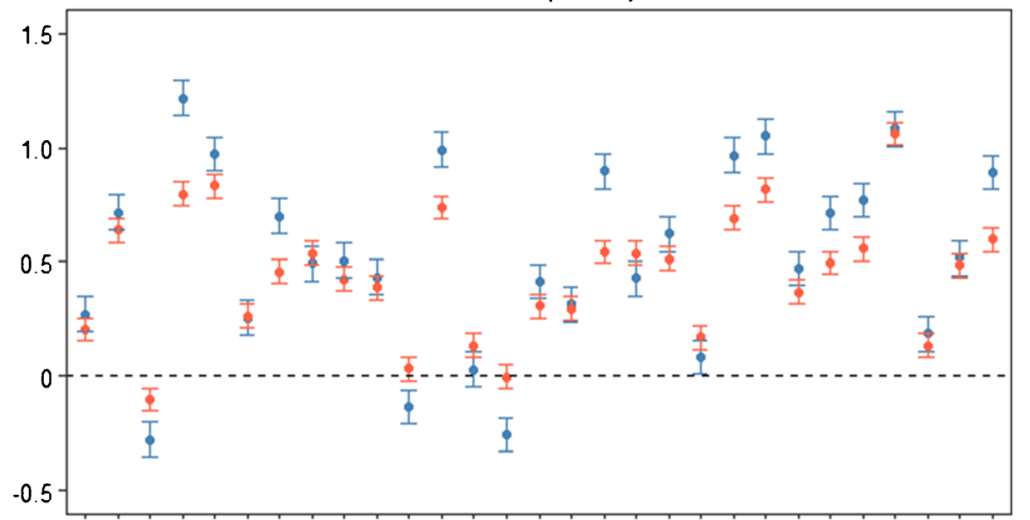

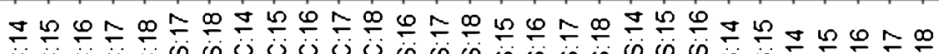

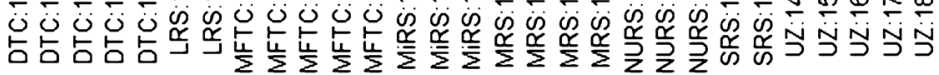

b Difference of BLUPs of ' $N T+M+R$ ' and ' $N T^{\prime}$ ( $t$ ha-1)

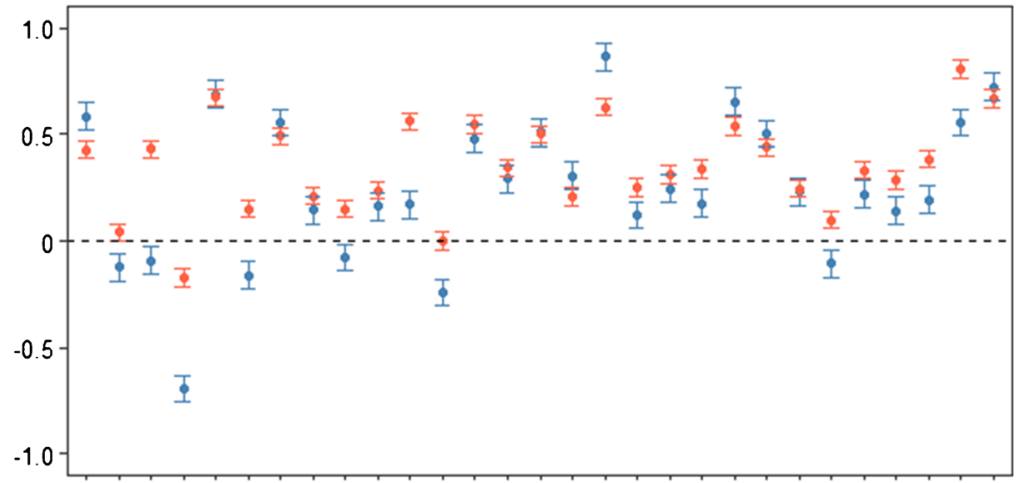

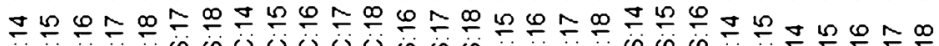

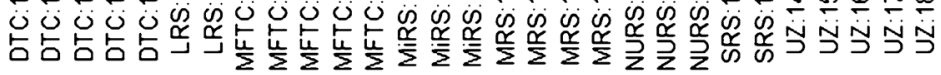
Environments 
and/or low rainfall, i.e., DTC:2016, MFTC:2017 and MiRS:2017 (Fig. S3).

Regarding cowpea, although grain yield and biomass did not differ among all cropping systems (Table 2 and Fig. 3b, d), $\mathrm{CT}+\mathrm{M}+\mathrm{R}$ performed similarly to $\mathrm{NT}+\mathrm{M}+\mathrm{R}$ in only $65 \%$ of environments (Fig. S4). Since our expectation was to have a similar performance in all environments, the fact that in 35\% of cases cowpea grain yield and biomass were different between systems might be due to drivers other than climate and soil texture, e.g., (non-)symbiotic microorganisms associated with nutrient cycling that would need to be investigated. This is also supported by the high percentage of variation in the response of grain yield and biomass explained by the interaction of locations and years (53\%) (Fig. S5).

Overall, our results are in line with the findings of Knapp and van der Heijden (2018) who highlighted that combining mulch and crop rotation with NT eliminates the yield gap with $\mathrm{CT}$. Mulch was recently identified as the most important of the three components of CA in sub-humid tropical regions (Kodzwa et al. 2020) due to its capacity to preserve soil moisture (Mupangwa et al. 2008; Thierfelder and Wall 2009) and to regulate soil temperature under erratic rainfalls and high air temperatures (Cook et al. 2006; Mupangwa et al. 2019). On the other hand, crop rotation with legumes contributes to biological $\mathrm{N}$ fixation as well as pest and disease reduction and thus affects soil fertility, particularly under conditions of $\mathrm{N}$ deficiency (Rusinamhodzi et al. 2011). However, although the adoption of crop rotation in southern Africa hinges on land availability and output markets for all crops, which are limited for smallholders (Snapp et al. 2002, 2010), it should be viewed in light of increasing food security and resilience (Fisher et al. 2018; Thierfelder et al. 2018).

\subsection{Yield stability}

Overall, yield stability of both maize and cowpea across environments varied among cropping systems (Table 3 ). The use of mulch combined with CT or NT resulted in significantly lower Shukla's stability variance on maize grain yield and shoot biomass compared with the other cropping systems, indicating that mulch promoted an increase in the stability of production (Table 3). Crop rotation and/or mulch together with $\mathrm{NT}(\mathrm{NT}+\mathrm{R}, \mathrm{NT}+\mathrm{M}+\mathrm{R})$ or $\mathrm{CT}(\mathrm{CT}+\mathrm{R}$ and $\mathrm{CT}+\mathrm{M}+\mathrm{R})$ led to the most unstable maize grain yield and aboveground shoot biomass (Table 3 ).

A meta-analysis synthetizing the response of field crops (i.e., sorghum, soybean, wheat, barley, maize, cotton, and rice) in terms of yield stability showed that the application of mulch and rotation in NT compared with CT had no effect on stability (Knapp and van der Heijden 2018). The disagreement between our results and these data can be due to the confounding effect of crop species and geographical areas. However, by focusing on maize and southern Africa, the unique synthesis of literature results compared only mulch plus NT vs NT (Rusinamhodzi et al. 2011). The regression analysis used for studying the stability of maize yield did not support the hypothesis of a more stable yield under mulch implementation. Similarly, including diversification in CA systems had slightly positive effects on maize yield stability across areas with different heat stress levels (Steward et al. 2018). Therefore, our novel finding that mulch largely stabilizes maize yield across southern Africa supports a generalized positive effect of this component of $\mathrm{CA}$ in buffering limiting factors across environments, such as soil moisture and temperature. Mulch allows maintaining suitable moisture and thermal environment in
Table 3 Shukla's stability variances (Shukla 1972) of grain yield and shoot biomass of maize (Zea mays L.) under eight cropping systems (i.e., conventional tillage-CT, CT plus mulch-M, CT plus rotation- $\mathrm{R}$, $\mathrm{CT}+\mathrm{M}+\mathrm{R}$, no-tillage- $\mathrm{NT}, \mathrm{NT}+\mathrm{M}$, $\mathrm{NT}+\mathrm{R}, \mathrm{NT}+\mathrm{M}+\mathrm{R}$ ) and of grain yield and shoot biomass of cowpea (Vigna unguiculata L.) under four cropping systems (i.e., $\mathrm{CT}+\mathrm{R}, \mathrm{CT}+\mathrm{M}+\mathrm{R}, \mathrm{NT}+\mathrm{R}, \mathrm{NT}+$

$M+R)$, as calculated across eight experimental locations in southern Africa, with four field replicates for each cropping system, and trial duration from 2 to 5 years

\begin{tabular}{|c|c|c|c|c|c|}
\hline \multirow[t]{2}{*}{ Crop } & \multicolumn{3}{|l|}{ Grain } & \multicolumn{2}{|l|}{ Shoot biomass } \\
\hline & Cropping system & $\begin{array}{l}\text { Shukla's stability } \\
\text { variance }\end{array}$ & $\mathrm{SE}^{\mathrm{a}}$ & $\begin{array}{l}\text { Shukla's stability } \\
\text { variance }\end{array}$ & SE \\
\hline \multirow[t]{8}{*}{ Maize } & $\mathrm{CT}$ & 0.44 & 0.13 & 0.32 & 0.10 \\
\hline & $\mathrm{CT}+\mathrm{M}$ & 0.21 & 0.07 & 0.16 & 0.05 \\
\hline & $\mathrm{CT}+\mathrm{R}$ & 0.45 & 0.13 & 0.37 & 0.11 \\
\hline & $\mathrm{CT}+\mathrm{M}+\mathrm{R}$ & 0.51 & 0.15 & 0.53 & 0.15 \\
\hline & NT & 0.30 & 0.09 & 0.18 & 0.06 \\
\hline & $\mathrm{NT}+\mathrm{M}$ & 0.34 & 0.10 & 0.20 & 0.07 \\
\hline & $\mathrm{NT}+\mathrm{R}$ & 0.54 & 0.16 & 0.43 & 0.13 \\
\hline & $\mathrm{NT}+\mathrm{M}+\mathrm{R}$ & 0.46 & 0.14 & 0.41 & 0.12 \\
\hline \multirow[t]{4}{*}{ Cowpea } & $\mathrm{CT}+\mathrm{R}$ & 0.05 & 0.03 & 0.44 & 0.15 \\
\hline & $\mathrm{CT}+\mathrm{M}+\mathrm{R}$ & 0.44 & 0.13 & 0.32 & 0.11 \\
\hline & $\mathrm{NT}+\mathrm{R}$ & 0.07 & 0.03 & 0.26 & 0.10 \\
\hline & $\mathrm{NT}+\mathrm{M}+\mathrm{R}$ & 0.12 & 0.05 & 0.12 & 0.07 \\
\hline
\end{tabular}

${ }^{a} \mathrm{SE}$, standard error 
soil, thus favoring the development of beneficial microorganisms promoting soil structure, nutrient release, and ultimately plant growth (Lal 1974; Bedini et al. 2009; Piazza et al. 2020). The implementation of NT or CT with mulch to obtain the highest maize production stability is of crucial importance in southern Africa where high rainfall variability together with low fertilizer application and other inadequate agronomic practices (e.g., wrong time of planting and insufficient weeding) are responsible for low crop yields and poor soil quality (Thierfelder et al. 2018; Steward et al. 2019).

Moreover, mulch did not affect the stability of cowpea yield under NT, whereas stability was reduced when associated with CT (Table 3). Finally, the combination of mulch and rotation did not modify the stability of cowpea biomass under both tillage systems. Less variable grain yields of cowpea, compared with maize, indicate a higher developmental plasticity in cowpea than in maize. Plastic growth is important particularly in southern Africa where rainfall periods vary among years as a consequence of the climate phenomena El

a $\operatorname{PC} 21.1 \%$

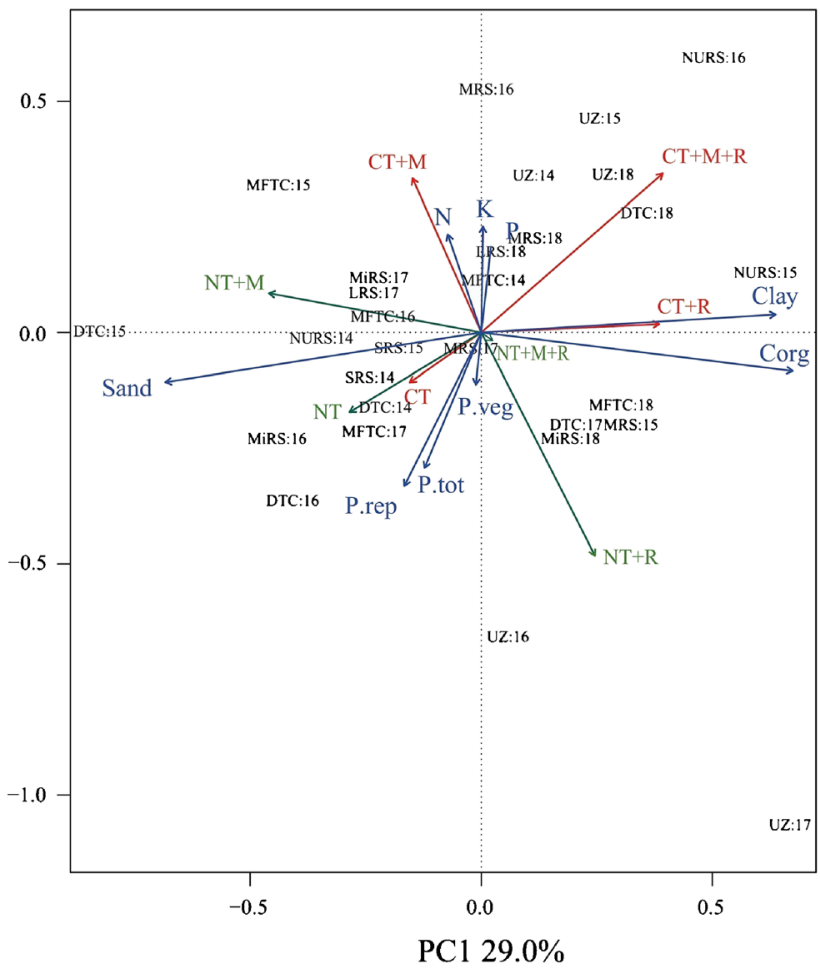

Fig. 5 Principal component (PC) analysis biplots of the additive and interaction effects of the factors location and year on (a) grain yield and (b) shoot biomass of maize (Zea mays L.) at eight locations in southern Africa, four field replicates for each cropping system, and trial duration from 2 to 5 years. The environmental variables precipitation (P.tot, total rainfall; P.veg, rainfall during the vegetative growth phase; P.rep, rainfall during the reproductive growth phase), application of available macronutrients nitrogen $(\mathrm{N})$, phosphorus $(\mathrm{P})$, and potassium $(\mathrm{K})$ with fertilization, soil texture (clay and sand), and soil organic carbon (Corg) were projected a posteriori on the ordination space. Abbreviations of cropping systems: $\mathrm{CT}$, conventional tillage; $\mathrm{CT}+\mathrm{M}$, CT plus mulch;
Niño and La Niña and of climatic change. Lower fertilizer expenses and a good local market also make cowpea a valuable rotational crop. Future experiments could, however, evaluate whether more drought-tolerant legumes, such as chickpea (Cicer arietinum L.), could be even better rotational crops than cowpea (Pellegrino and Bedini 2014; Avola et al. 2018).

To better understand the variable relationships between the cropping systems and the environments in terms of stability, we used the AMMI analyses and plotted the results in biplots. The first two principal components of the biplots accounted for $50.1 \%$, $51.6 \%, 67.9 \%$, and $71.1 \%$ of the original variance of the "system $\times$ environment" interaction for maize grain, maize biomass, cowpea grain, and cowpea biomass, respectively (Fig. 5 and Fig. S5).

The stability of maize grain yield and biomass under NT+ $\mathrm{M}$ was positively associated with sandy soil environments under high rainfall and fertilizer application (e.g., MFTC:16 and LRS:17), whereas under $\mathrm{CT}+\mathrm{M}$ it was positively associated with sandy soils under low rainfall and high fertilizer application (e.g., MFTC:14 and MRS:16) (Fig. 5).

b $_{\text {PC2 } 23.4 \%}$

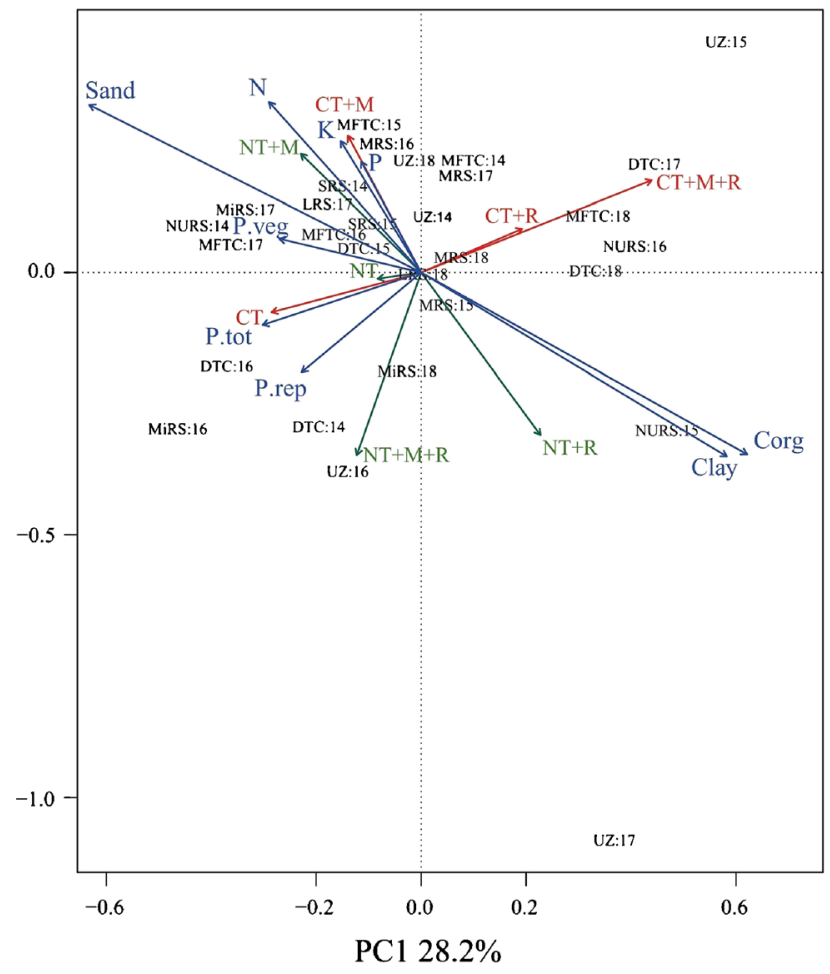

$\mathrm{CT}+\mathrm{R}, \mathrm{CT}$ plus crop rotation; $\mathrm{CT}+\mathrm{M}+\mathrm{R}, \mathrm{CT}$ plus mulch and rotation; $\mathrm{NT}$, no-tillage; NT+M, NT plus mulch; NT+R, NT plus rotation; NT+M+ $\mathrm{R}$, NT plus mulch and rotation. Conventional tillage-based systems are shown in red while those based on no-tillage are shown in green. Abbreviations of the trial locations: NURS, Ntengo Umodzi; SRS, Sussundenga Research Station; LRS, Lisello Research Station; MiRS, Misamfu Research Station; MFTC, Monze Farmer Training Centre; MRS, Msekera Research Station; DTC, Domboshava Training Centre; UZ, University of Zimbabwe farm. The numbers after the location name represent the last two digits of the year 
Previously, in a regression analysis used to study the stability of maize yield in southern Africa, NT with mulch had a smaller regression coefficient in sandy soils than in clay soils, suggesting an advantage of mulch systems to optimize moisture availability in soils of poor drainage (Rusinamhodzi et al. 2011). Thus, our results add novel findings to dissect the effect of mulch on maize yield stabilization, as under NT the advantage in high rainfall areas is probably associated with reduced risks of waterlogging, while under CT the advantage in low rainfall areas is probably associated with an increase of soil moisture availability due to reduced evapotranspiration. Mulch added to NT or CT proved to be more effective in enhancing maize yield stability in sandy soils under application of more $\mathrm{N}, \mathrm{P}$, and $\mathrm{K}$ fertilizer because it may compensate $\mathrm{N}$ immobilization in microbial biomass, particularly during the early years of CA implementation (Gentile et al. 2009; Mupangwa et al. 2019). Thus, our analyses on yield stability under the diverse conditions ("environments") hint at rainfall and fertilizer as the primary influencers. Any measure to ameliorate these two most limiting factors could thus sustainably boost maize stability. However, since irrigation and mineral fertilizers are expensive and often not readily available for smallholder farmers (Tittonell et al. 2008), there is a further need to elucidate and ultimately manage the yield-determining regulatory processes at the soil-plant interface (i.e., crop rhizosphere) (Bender et al. 2016; Ciccolini et al. 2016).

By contrast, the stability of maize production under NT+R and $\mathrm{NT}+\mathrm{M}+\mathrm{R}$ was positively associated with high rainfall and clay and organic $\mathrm{C}$ in soil (e.g., UZ:16), whereas under $\mathrm{CT}+\mathrm{R}$ and $\mathrm{CT}+\mathrm{M}+\mathrm{R}$ it was positively associated with low rainfall and clay and organic $\mathrm{C}$ in soil (e.g., UZ:18 and NURS:15) (Fig. 5). These results confirmed our previous findings that maize yield stability under $\mathrm{NT}+\mathrm{M}$ and $\mathrm{CT}+\mathrm{M}$ is positively associated with high and low rainfall, respectively. Moreover, soil texture was confirmed to be a key mediator of the performance of CA also considering yield stability under high as well as low rainfall. Our analyses on maize yield stability also revealed combinations of locations and years (NURS:16, UZ:15, UZ:17) under which none of the CA components could prevent fluctuations in maize yield, also not under drought (UZ:15) or high rainfall fluctuations during the critical growth stages. Negative consequences of extreme rainfall conditions can thus not be offset (Rusinamhodzi et al. 2011).

Regarding cowpea, the stability of grain yield under NT+ $\mathrm{M}+\mathrm{R}$ and $\mathrm{CT}+\mathrm{M}+\mathrm{R}$ was positively associated with dry and humid environments respectively, and with soils with high clay content and organic $\mathrm{C}$ (e.g., NT+M+R: MRS:18; $\mathrm{CT}+\mathrm{M}+\mathrm{R}$ : MRS:16) (Fig. S6). Similar to maize yield stability, clay soils promoted more stable yields under both full $\mathrm{CA}$ and $\mathrm{CT}+\mathrm{M}+\mathrm{R}$. Moreover, under dry conditions, soil moisture was promoted by full CA, whereas under humid conditions it was promoted by $\mathrm{CT}+\mathrm{M}+\mathrm{R}$. This confirmed that yield-limiting factors that are offset by tillage plus mulch and rotation are the reduction of evapotranspiration under dry conditions and the increase of drainage under humid conditions. Finally, the stability of cowpea yield under $\mathrm{NT}+\mathrm{R}$ and $\mathrm{CT}+\mathrm{R}$ was positively associated with sandy soils under high rainfall (e.g., NT+R: DTC:17; CT+R: MRS:17), supporting the fact that cowpea stability is highly negatively affected by waterlogging.

\section{Conclusions}

Several studies have assessed how different combinations of CA components affect crop yield response. However, no study has assessed how all possible combinations of these CA components affect crop yield stability across diverse environments. Hence, we focused our study on yield stability together with yield responses across southern Africa. We showed that full CA and for the first time $\mathrm{CT}+\mathrm{M}+\mathrm{R}$, which is a system rarely implemented in southern Africa, should be promoted as effective strategies to improve crop yield. In addition, this positive response was shown to be generalized across environments. Cowpea yields were shown to be unaffected by tillage system (NT vs CT) and the implementation of CA practices $(\mathrm{NT}+\mathrm{M}+\mathrm{R}$ vs $\mathrm{NT}$ and $\mathrm{CT}+\mathrm{M}+\mathrm{R}$ vs $\mathrm{CT}$ ), supporting previous hypothesis that legume crops are less susceptible than cereals to potential yield-limiting factors associated with NT. Nevertheless, since we highlighted cowpea grain yield differences between full $\mathrm{CA}$ and $\mathrm{CT}+\mathrm{M}+\mathrm{R}$ in a relevant proportion of locations and years, we conclude that drivers other than climate and soil texture are involved in the regulation of the mechanisms of response of legume rotational crops under these systems. Finally, we have shown for the first time that the addition of mulch either to NT or CT systems mostly stabilizes maize yield across different environments in southern Africa. This pointed out the importance of mulch in mitigating the effects of common main limiting factors, such as moisture stress and poor soil fertility, across most of the environments. We also found for the first time that the mechanisms of maize yield stabilization are mainly explained by the quantity of rainfall and applied mineral fertilizers, as well as soil texture. Thus, mulching can be addressed as the most promising measure to improve maize yield stability in southern Africa under climate change scenario.

Supplementary Information The online version contains supplementary material available at https://doi.org/10.1007/s13593-021-00687-y.

Acknowledgements $\mathrm{BM}$ acknowledges $\mathrm{PhD}$ fellowship funding by Scuola Superiore Sant'Anna. The authors thank Dr H. A. Gamper for his valuable comments on an earlier version of the manuscript. All the authors are grateful to the International Maize and Wheat Improvement Centre for funding the setup and running of the experimental trials. We 
further thank the donors of the MAIZE CGIAR Research Program (www. maize.org) who supported the trials until 2018 and the USAID-funded Feed the Future Project Africa Research In Sustainable Intensification for the next Generation (Africa RISING) for financial support. Special thanks go to the technical personnel at each experimental location that assisted in data collection.

Availability of data and material Data used in this study is stored in a public data repository and can be made available upon reasonable request following data-sharing regulations.

Code availability The scripts used in data analyses in R environment are available from the corresponding author upon reasonable request.

Author contribution CT designed and initiated the experimental trials and coordinated data collection. BM and AO analyzed the data. BM and $\mathrm{CT}$ wrote the first draft and LE, EP, and AO jointly contributed to the writing and revision of the manuscript.

Funding Open access funding provided by Scuola Superiore Sant'Anna within the CRUI-CARE Agreement. Funding for these trials was received through a range of financing agreements including the USAID-funded Feed the Future projects, Sustainable Intensification in Maize-Legume Systems in Eastern Province of Zambia (SIMLEZA, Grant No. EEMG-00-04-00013), and Africa Research in Sustainable Intensification for the Next Generation (Africa RISING, AID-BFS-G-11-00002); grants from the Bundesministerium für wirtschaftliche Zumsammenarbeit (BMZ/GIZ Grant No. 13.22.44.5-002.00 and 13.9767.8-002.00), and the International Fund for Agriculture Development (IFAD, Grant No. 1309).

\section{Declarations}

Ethics approval All ethics committees of the organizations with which the authors are affiliated have no objections to the publication of this work.

Consent to participate Not applicable.

Consent for publication Not applicable.

Conflict of interest The authors declare no competing interests.

Open Access This article is licensed under a Creative Commons Attribution 4.0 International License, which permits use, sharing, adaptation, distribution and reproduction in any medium or format, as long as you give appropriate credit to the original author(s) and the source, provide a link to the Creative Commons licence, and indicate if changes were made. The images or other third party material in this article are included in the article's Creative Commons licence, unless indicated otherwise in a credit line to the material. If material is not included in the article's Creative Commons licence and your intended use is not permitted by statutory regulation or exceeds the permitted use, you will need to obtain permission directly from the copyright holder. To view a copy of this licence, visit http://creativecommons.org/licenses/by/4.0/.

\section{References}

Avola G, Riggi E, Gresta F, Sortino O, Onofri A (2018) Random effects models, BLUPs and redundancy analyses for grain legume crops in semi-arid environments. Eur J Agron 93:18-26. https://doi.org/10. 1016/j.eja.2017.11.004

Bates D, Maechler M, Bolker B, Walker S (2015) Fitting linear mixedeffects models using lme4. J Stat Softw 67:1-48. https://doi.org/10. 18637/jss.v067.i01

Bedini S, Pellegrino E, Avio L, Pellegrini S, Bazzoffi P, Argese E, Giovannetti M (2009) Changes in soil aggregation and glomalinrelated soil protein content as affected by the arbuscular mycorrhizal fungal species Glomus mosseae and Glomus intraradices. Soil Biol Biochem 41:1491-1496. https://doi.org/10.1016/j.soilbio.2009.04. 005

Bender SF, Wagg C, van der Heijden MGA (2016) An underground revolution: biodiversity and soil ecological engineering for agricultural sustainability. Trends Ecol Evol 31:440-452. https://doi.org/ 10.1016/j.tree.2016.02.016

Bonciarelli U, Onofri A, Benincasa P, Farneselli M, Guiducci M, Pannacci E, Tosti G, Tei F (2016) Long-term evaluation of productivity, stability and sustainability for cropping systems in Mediterranean rainfed conditions. Eur J Agron 77:146-155. https://doi.org/10.1016/j.eja.2016.02.006

Borcard D, Gillet F, Legendre P (2018) Numerical ecology with R, 2nd edn. Springer International Publishing, New York

Bretz F, Hothorn T, Westfall P (2016) Multiple comparisons using R. CRC Press, Florida

Brouder SM, Gomez-Macpherson H (2014) The impact of conservation agriculture on smallholder agricultural yields: a scoping review of the evidence. Agric Ecosyst Environ 187:11-32. https://doi.org/10. 1016/j.agee.2013.08.010

Butler D, Cullis B, Gilmour A, Gogel B (2009) ASReml-R reference manual: mixed models for S Language environments. Queensland Government, Department of Primary Industries and Fisheries, Brisbane, Australia

Cheesman S, Thierfelder C, Eash NS, Kassie GT, Frossard E (2016) Soil carbon stocks in conservation agriculture systems of Southern Africa. Soil Tillage Res 156:99-109. https://doi.org/10.1016/j.still. 2015.09.018

Ciccolini V, Ercoli L, Davison J, Vasar M, Öpik M, Pellegrino E (2016) Land-use intensity and host plant simultaneously shape the composition of arbuscular mycorrhizal fungal communities in a Mediterranean drained peatland. FEMS Microbiol Ecol 92:fiw186. https://doi.org/10.1093/femsec/fiw186

Cook HF, Valdes GSB, Lee HC (2006) Mulch effects on rainfall interception, soil physical characteristics and temperature under Zea mays L. Soil Tillage Res 91:227-235. https://doi.org/10.1016/j. still.2005.12.007

Corbeels M, Naudin K, Whitbread AM, Kühne R, Letourmy P (2020) Limits of conservation agriculture to overcome low crop yields in sub-Saharan Africa. Nat Food 1:447-454. https://doi.org/10.1038/ s43016-020-0114-x

Craven M, Nel AA (2017) Effect of conservation agriculture associated crop rotation systems on root and crown rot severity and respective soil-borne pathogens of maize (Zea mays $L$.) in the Highveld area of South Africa. South Afr J Plant Soil 34:87-95. https://doi.org/10. 1080/02571862.2016.1213322

Ercoli L, Masoni A, Mariotti M, Pampana S, Pellegrino E, Arduini I, (2017) Effect of preceding crop on the agronomic and economic performance of durum wheat in the transition from conventional to reduced tillage. Eur J Agron 82:125-133. https://doi.org/10.1016/j. eja.2016.10.010

Esmeraldo MQ (2017) Effects of tillage practices on some key soil parameters: a case study in the Kwazulu-Natal Midlands, South Africa (Master of Science). Stellenbosch University, Cape Town, South Africa

FAO (2012) Conservation agriculture.www.fao.org/reliefoperations (accessed 17 August, 2013) 
Fisher M, Holden ST, Thierfelder C, Katengeza SP (2018) Awareness and adoption of conservation agriculture in Malawi: what difference can farmer-to-farmer extension make? Int J Agric Sustain 16:310 325. https://doi.org/10.1080/14735903.2018.1472411

Gauch HG, Piepho HP, Pannacci E, Guiducci M (2008) Statistical analysis of yield trials by AMMI and GGE: further considerations. Crop Sci 48:866-889. https://doi.org/10.2135/cropsci2007.09.0513

Gentile R, Vanlauwe B, van Kessel C, Six J (2009) Managing N availability and losses by combining fertilizer- $\mathrm{N}$ with different quality residues in Kenya. Agric Ecosyst Environ 131:308-314. https://doi. org/10.1016/j.agee.2009.02.003

Giller KE, Andersson JA, Corbeels M, Kirkegaard J, Mortensen D, Erenstein O, Vanlauwe B (2015) Beyond conservation agriculture. Front Plant Sci 6:870. https://doi.org/10.3389/fpls.2015.00870

Hanway JJ (1963) Growth stages of maize (Zea mays L.). Agron J 55:487492. https://doi.org/10.2134/agronj1963.00021962005500050024x

Hermans TDG, Whitfield S, Dougill AJ, Thierfelder C (2020) Bridging the disciplinary gap in conservation agriculture research, in Malawi. A review. Agron Sustain Dev 40:3. https://doi.org/10.1007/s13593020-0608-9

IUSS Working Group WRB (2015) World reference base on soils (world soil resources reports no. 106), international soil classification system for naming soils and creating legends for soil maps. FAOISRIC, Rome, Italy

Kassam A, Friedrich T, Derpsch R, Kienzle J (2015) Overview of the worldwide spread of conservation agriculture. Field Actions Science Reports. J Field Actions 8:1-10 http://journals.openedition.org/ factsreports/3966

Kassam A, Friedrich T, Derpsch R (2019) Global spread of conservation agriculture. Int J Environ Stud 76(1):29-51. https://doi.org/10.1080/ 00207233.2018.1494927

Knapp S, van der Heijden MGA (2018) A global meta-analysis of yield stability in organic and conservation agriculture. Nat Commun 9: 3632. https://doi.org/10.1038/s41467-018-05956-1

Kodzwa JJ, Gotosa J, Nyamangara J (2020) Mulching is the most important of the three conservation agriculture principles in increasing crop yield in the short term, under sub humid tropical conditions in Zimbabwe. Soil Tillage Res 197:104515. https://doi.org/10.1016/ j.still.2019.104515

Lal R (1974) Soil temperature, soil moisture and maize yield from mulched and unmulched tropical soils. Plant Soil 40:129-143. https://doi.org/10.1007/BF00011415

Lenth R (2019) emmeans: estimated marginal means, aka least-squares means. R package version 1.3.4. https://CRAN.R-project.org/ package $=$ emmeans

Ligowe IS, Naliyata PC, Njoloma J, Makumba W, Thierfelder C (2017) Medium-term effects of conservation agriculture on soil quality. Afr J Agric Res 12:2412-2420. https://doi.org/10.5897/AJAR2016. 11092

Mafongoya PL, Jiri O (2015) Impact of conservation agriculture on weed dynamics and maize grain yield in eastern Zambia. Afr J Agric Res 10:4231-4240. https://doi.org/10.5897/AJAR2013.8111

Mhlanga B, Cheesman S, Maasdorp B, Muoni T, Mabasa S, Mangosho E, Thierfelder C (2015) Weed community responses to rotations with cover crops in maize-based conservation agriculture systems of Zimbabwe. Crop Prot 69:1-8. https://doi.org/10.1016/j.cropro. 2014.11.010

Mupangwa W, Twomlow S, Walker S (2008) Conservation tillage for soil water management in the semi arid southern Zimbabwe. Phys Chem Earth 33:762-767. https://doi.org/10.1016/j.pce.2008.06.049

Mupangwa W, Thierfelder C, Cheesman S, Nyagumbo I, Muoni T, Mhlanga B, Mwila M, Sida TS, Ngwira A (2019) Effects of maize residue and mineral nitrogen applications on maize yield in conservation-agriculture-based cropping systems of Southern Africa. Renew Agric Food Syst:1-4. https://doi.org/10.1017/ S174217051900005X
Ngwira A, Johnsen FH, Aune JB, Mekuria M, Thierfelder C (2014) Adoption and extent of conservation agriculture practices among smallholder farmers in Malawi. J Soil Water Conserv 69:107-119. https://doi.org/10.2489/jswc.69.2.107

Nyamangara J, Nyengerai K, Masvaya EN, Tirivavi R, Mashingaidze AB, Mupangwa W, Dimes J, Hove L, Twomlow S (2014) Effect of conservation agriculture on maize yield in the semi-arid areas of Zimbabwe. Exp Agric 50:159-177. https://doi.org/10.1017/ S0014479713000562

Oksanen J, Blanchet FG, Friendly M, Kindt R, Legendre P, McGlinn D, Minchin PR, O'Hara RB, Simpson GL, Solymos P, Henry M, Stevens H, Szoecs E, Wagner H (2019) vegan: community ecology package. R package version 2.5-5. https://CRAN.R-project.org/ package $=$ vegan

Onofri A, Seddaiu G, Piepho HP (2016) Long-term experiments with cropping systems: case studies on data analysis. Eur J Agron 77: 223-235. https://doi.org/10.1016/j.eja.2016.02.005

Pellegrino E, Bedini S (2014) Enhancing ecosystem services in sustainable agriculture: biofertilization and biofortification of chickpea (Cicer arietinum L.) by arbuscular mycorrhizal fungi. Soil Biol Biochem 68:429-439. https://doi.org/10.1016/j.soilbio.2013.09.030

Piazza G, Pellegrino E, Moscatelli MC, Ercoli L (2020) Long-term conservation tillage and nitrogen fertilization effects on soil aggregate distribution, nutrient stocks and enzymatic activities in bulk soil and occluded microaggregates. Soil Tillage Res 196:104482. https://doi. org/10.1016/j.still.2019.104482

Piepho HP (1998) Methods for comparing the yield stability of cropping systems. J Agron Crop Sci 180:193-213. https://doi.org/10.1111/j. 1439-037X.1998.tb00526.x

Pittelkow CM, Liang X, Linquist BA, van Groenigen KJ, Lee J, Lundy ME, van Gestel N, Six J, Venterea RT, van Kessel C (2015) Productivity limits and potentials of the principles of conservation agriculture. Nature 517:365-368. https://doi.org/10.1038/ nature 13809

Powlson DS, Stirling CM, Thierfelder C, White RP, Jat ML (2016) Does conservation agriculture deliver climate change mitigation through soil carbon sequestration in tropical agro-ecosystems? Agric Ecosyst Environ 220:164-174. https://doi.org/10.1016/j.agee.2016. 01.005

R Core Team (2019) R: a language and environment for statistical computing. R Foundation for Statistical Computing, Vienna, Austria URL https://www.R-project.org/

Rusinamhodzi L, Corbeels M, Van Wijk MT, Rufino MC, Nyamangara J, Giller KE (2011) A meta-analysis of long-term effects of conservation agriculture on maize grain yield under rain-fed conditions. Agron Sustain Dev 31:657-673. https://doi.org/10.1007/s13593011-0040-2

Shukla GK (1972) Some statistical aspects of partitioning genotypeenvironmental components of variability. Heredity 29:237-245. https://doi.org/10.1038/hdy.1972.87

Snapp SS, Rohrbach DD, Simtowe F, Freeman HA (2002) Sustainable soil management options for Malawi: can smallholder farmers grow more legumes? Agric Ecosyst Environ 91:159-174. https://doi.org/ 10.1016/S0167-8809(01)00238-9

Snapp SS, Blackie MJ, Gilbert RA, Bezner-Kerr R, Kanyama-Phiri GY (2010) Biodiversity can support a greener revolution in Africa. Proc Natl Acad Sci 107:20840. https://doi.org/10.1073/pnas.1007199107

Steward PR, Dougill AJ, Thierfelder C, Pittelkow CM, Stringer LC, Kudzala M, Shackelford GE (2018) The adaptive capacity of maize-based conservation agriculture systems to climate stress in tropical and subtropical environments: a meta-regression of yields. Agric Ecosyst Environ 251:194-202. https://doi.org/10.1016/j.agee. 2017.09.019

Steward PR, Thierfelder C, Dougill AJ, Ligowe I (2019) Conservation agriculture enhances resistance of maize to climate stress in a 
Malawian medium-term trial. Agric Ecosyst Environ 277:95-104. https://doi.org/10.1016/j.agee.2018.07.009

Thierfelder C, Wall PC (2009) Effects of conservation agriculture techniques on infiltration and soil water content in Zambia and Zimbabwe. Soil Tillage Res 105:217-225. https://doi.org/10.1016/ j.still.2009.07.007

Thierfelder C, Wall PC (2010) Rotations in conservation agriculture systems of Zambia: effects on soil quality and water relations. Exp Agric 46:1-7. https://doi.org/10.1017/S001447971000030X

Thierfelder C, Mombeyarara T, Mango N, Rusinamhodzi L (2013) Integration of conservation agriculture in smallholder farming systems of southern Africa: identification of key entry points. Int $\mathrm{J}$ Agric Sustain 11:317-330. https://doi.org/10.1080/14735903. 2013.764222

Thierfelder C, Rusinamhodzi L, Ngwira A, Mupangwa W, Nyagumbo I, Kassie GT, Cairns JE (2014) Conservation agriculture in Southern Africa: advances in knowledge. Renew Agric Food Syst 30:328348. https://doi.org/10.1017/S1742170513000550

Thierfelder C, Baudron F, Setimela P, Nyagumbo I, Mupangwa W, Mhlanga B, Lee N, Gérard B (2018) Complementary practices supporting conservation agriculture in southern Africa. A review. Agron Sustain Dev 38:16. https://doi.org/10.1007/s13593-0180492-8

Tittonell P, Vanlauwe B, Corbeels M, Giller KE (2008) Yield gaps, nutrient use efficiencies and response to fertilisers by maize across heterogeneous smallholder farms of western Kenya. Plant Soil 313: 19-37. https://doi.org/10.1007/s11104-008-9676-3

Urruty N, Tailliez-Lefebvre D, Huyghe C (2016) Stability, robustness, vulnerability and resilience of agricultural systems. A review. Agron Sustain Dev 36:15. https://doi.org/10.1007/s13593-015-0347-5

Valbuena D, Erenstein O, Homann-Kee Tui S, Abdoulaye T, Claessens L, Duncan AJ, Gérard B, Rufino MC, Teufel N, van Rooyen A, van Wijk MT (2012) Conservation agriculture in mixed crop-livestock systems: scoping crop residue trade-offs in Sub-Saharan Africa and South Asia. Field Crop Res 132:175-184. https://doi.org/10.1016/j. fcr.2012.02.022

Ward PS, Bell AR, Droppelmann K, Benton TG (2018) Early adoption of conservation agriculture practices: understanding partial compliance in programs with multiple adoption decisions. Land Use Policy 70: 27-37. https://doi.org/10.1016/j.landusepol.2017.10.001

Zhao X, Tong C, Pang X, Wang Z, Guo Y, Du F, Wu R (2011) Functional mapping of ontogeny in flowering plants. Brief Bioinform 13:317-328. https://doi.org/10.1093/bib/bbr054

Zobel RW, Wright MJ, Gauch HG (1988) Statistical analysis of a yield trial. Agron J 80:388-393. https://doi.org/10.2134/agronj1988. $00021962008000030002 \mathrm{x}$

Publisher's note Springer Nature remains neutral with regard to jurisdictional claims in published maps and institutional affiliations. 